\title{
Effect of some mutagens for induced mutation and detected variation by SSR marker in bread wheat (Triticum aestivum L.)
}

\author{
Abdel-Hamed A. A.*, El-Sheihk Aly M. M., Saber Sh. M.
}

Agricultural Botany Department, Faculty of Agriculture, Al-Azhar University, 71524 Assiut, Egypt

\begin{abstract}
Two chemical mutagens sodium azid (SA) and hydrazine hydrate (HZ) were used to induce genetic variability for improving some morphological and agronomical traits in three bread wheat genotypes namely, Sids 1 , Sids 12 and Giza168. Some mutations were selected in $M_{1}$ generation plants i.e., three for Sids 1 variety $\left(S_{1} 29, S_{1} 49\right.$, and $\left.S_{1} 75\right)$, four for Sids 12 variety i.e., $\left(S_{12} 116, S_{12} 161, S_{12} 168\right.$ and $\left.S_{1 d s} 177\right)$ and one for Giza168 $\left(G_{168} 202\right)$. Selected genotypes were grown in field experiment to obtain $\mathrm{M}_{2}$ generation. Results showed that most agronomical traits were significantly increased in $\mathrm{M}_{2}$ than $\mathrm{M}_{1}$ generation plants. The highest values in selected mutated plants for 100 grain weight were $6.31 \mathrm{gm}$ for $\mathrm{S}_{12} 161$ plant, $5.79 \mathrm{gm}$ for $\mathrm{G}_{168} 202$ plant and $5.55 \mathrm{gm}$ for $\mathrm{S}_{1} 29$ plant. Genetic variation in $\mathrm{M}_{2}$ plants were used of evaluated by SSR molecular markers. The results showed representable the variation between treated genotypes and untreated (control) for all studied traits.
\end{abstract}

Keywords: bread wheat, sodium azid, hydrazine hydrate, SSR marker, mutation. 


\section{Introduction}

Wheat (Triticum aestivum L.) belongs to the grass family Poaceae and considered one of the most important food crops in the world. with genome size ( 17.6 GB) (Hussain et al., 2018; Mohamed et al., 2018; Nielsen et al., 2014). Bread wheat is an allohexaploid species $(2 \mathrm{n}=6 \mathrm{x}=42)$ (Babben et al., 2018). In Egypt, wheat is one of the oldest and most important cereal crops (Al-Naggar et al., 2015). Physical and chemical mutagens have been induced for various plant characters in variety of crops including wheat (Singh and Balyan, 2009). Induction of mutation in crop plants contribute by increasing genetic variability and enrich plant germplasm for direct selection and cross-breeding. Induction of mutation has been applied to produce mutant plants vary by changing the plant characteristics for a significant increase in production and improve quality (Nazarenko, 2016). Sodium azide (SA) used with seeds to create mutation. Sodium azide is a very potent mutagen in barley and induced chlorophyll deficiency as well as a wide range of morphological and physiological variation (Pande and Khetmalas, 2012). Also, hydrazine hydrate (HZ) wase used to induce mutations (Laskar and Khan, 2017). chlorophyll mutations induced by ethylmethane sulphonate (EMS) - an alkylating agent, hydrazine hydrate (HZ) - a base analogue and sodium azide (SA) (Wani, 2017). Molecular markers have been proved valuable tools in the characterization and evaluation of genetic diversity within and between species and populations (Sadigova et al., 2014). Assessment of genetic diversity, increasing the efficiency of selection for both qualitative and quantitative traits can be achived with DNA marker (El-Sherbeny et al., 2020; Farhan et al., 2019). Sequence Tagged Sites (STS), and Random Amplified Microsatellite Polymorphism (RAMP) (Altintas et al., 2008; Ercan et al., 2010). Several PCR based molecular markers are available for investigation of genetic diversity. SSR, RAPD, AFLP and ISSR (Singh and Singh, 2018). This study aims to use chemical mutagens to induced morphological and agronomical variations in three widely different varieties of bread wheat and to use simple sequence repeats (SSR) molecular markers to detect the variation between treated varieties and their untreated varieties (control) for all studied traits.

\section{Materials and methods}

\subsection{Field materials}

Three genotypes of bread wheat were used in this study namely $\operatorname{Sids}_{1}, \operatorname{Sids}_{12}$ and Giza 168 . The pedigree and origin of these genotypes are shown in Table (1). In season 2018/2019, dry seeds ( 200 grain/ treatment) were soaked into distilled water for $16 \mathrm{~h}$ then soaked in three concentraions of both sodium azid (SA) and hydrazine hydrate (HZ) i.e., (0.0, $0.01,0.02$ and $0.03 \%$ ) for $16 \mathrm{~h}$. Treated seeds were washed in distilled water for 2 h. Grains from each of the three genotypes and treated seeds were sown in soil The experimental plot consisted of five rows $2.5 \mathrm{~m}$ long and $20 \mathrm{~cm}$ apart. a field trail to obtain $\mathrm{M}_{1}$ generation. In season 2019/2020, selected eight mutant plants 
genotypes were and sown in the Faculty, Al-Azhar University, Assuit, Experimental Farm of Agriculture Egypt to obtain $\mathrm{M}_{2}$ generation.

Table (1): The pedigree and origin of the three bread wheat genotypes used in this study.

\begin{tabular}{|l|l|l|}
\hline Name & Pedigree & Origin \\
\hline Sids $_{1}$ & MRL/BUC/SER1 & Egypt \\
\hline Sids $_{12}$ & $\begin{array}{l}\text { BUC//7C/ALD/5/MAYA74/0N//1160 } \\
\text { Egypt/47/3/BB/GLL/4/CHAT"S"/6/MAYA/VUL- } \\
\text { //CMH74A.63014*SX.SD7096-4SD-1SD-1SD-0SD }\end{array}$ & Egypt \\
\hline Giza $_{168}$ & $\begin{array}{l}\text { MRL/ BUC // SERI - CM 930 46- 8M-OY-OM-2Y- } \\
\text { OB-OGZ }\end{array}$ & Egypt \\
\hline
\end{tabular}

2.2 Genomic DNA isolation and SSR analysis

Genomic DNA of wheat was extracted from the young leaves by CTAB methods (Doyle and Doyle, 1987). Seven SSR primer combinations were used (Table 2). For each primer combinations, $25 \mu \mathrm{L}$ PCR reaction contained $5 \mu \mathrm{L}$ buffer $(5 \mathrm{x})$, $1.5 \mu \mathrm{L}$ of genomic DNA (30 ng), $2 \mu \mathrm{L}$ of $25 \mathrm{mM}$ of $\mathrm{MgCl}_{2}, 0.5 \mu \mathrm{L}$ of $10 \mathrm{mM}$ dNTPs and $0.15 \mu \mathrm{L}$ of Taq DNA polymerase. PCR amplifications for SSR analysis were performed in Applied Biosystems 2720 thermal cycler system, with initial denaturation at $94^{\circ} \mathrm{C}$ for 5 minutes followed by 40 cycles, each consisted of denaturation at $94^{\circ} \mathrm{C}$ for 50 seconds, annealing at $52^{\circ} \mathrm{C}$ for 1 minute, extension at $72^{\circ} \mathrm{C}$ for 1 minute, with final extension at $72^{\circ} \mathrm{C}$ for 7 minutes. PCR products were separated on $1.5 \%$ agarose gels, stained with ethidium bromide, and visualized on UV transilluminator. The gel was photographed using bio-print camera.

Table (2): SSR Primer sequences used to amplify molecular markers.

\begin{tabular}{|l|l|l|}
\hline Code & Sequences (5-3) & References \\
\cline { 1 - 2 } Xgwm 99 & $\begin{array}{l}\text { F- AAGATGGACGTATGCATCACA } \\
\text { R- GCCATATTTGATGACGCATA }\end{array}$ & \multirow{2}{*}{ Ateş Sönmezoğlu } \\
Xnd Terzi (2018)
\end{tabular}




\subsection{Statistical analysis}

The experimental design was Randomized Complete Blocks Design (RCBD). The analysis of variance (ANOVA) and Duncan multiple range testes at $5 \%$ level of probability were used to test the significant of differences between the treatments. Statistical analyses of data were performed using Costat software (Steel and Torrie, 1986). Gel images detected via PCR-based methods were analyzed using the free software Gel Analyzer 3 which is available at http://www.geocities.com/egygene (Gel Analyzer Version 3, 2007).

\section{Results and Discussion}

3.1 Mean performance of the three genotypes in first mutagenicity $\left(M_{1}\right)$ and second mutagenicity $\left(M_{2}\right)$ generations for the studied traits

\subsubsection{Sids 1}

The presented results in Table (3) showed that means of the studied traits i.e., plant height, number of spikes/plant, spike length, number of spikelets /spike, number of grains / spikelets and 100 grain weight in $\mathrm{M}_{1}$ and $\mathrm{M}_{2}$ generations of Sids1 genotype and its mutant selected plants i.e., $S_{1} 29, S_{1} 42$ and $S_{1} 75$ plants. Results showed that some mutations in Sids1 genotype increased in $M_{2}$ than $M_{1}$ generations. The highest value in plant height was $121.6 \mathrm{~cm}$ which obtained with $0.03 \% \mathrm{HZ}$ for mutated plant $S_{1} 75$ as compared to untreated plants (control) with $104.6 \mathrm{~cm}$. While the highest value in number of spikes /plant was 58.7 obtained with $0.02 \%$ SA for mutated plant $S_{1} 29$ as compared to original plants (control) with 12.9 spike. The highest value of spike length was $19.1 \mathrm{~cm}$ obtained at $0.02 \% \mathrm{SA}$ for mutated plant $S_{1} 29$ as compared to untreated plants (control) with $13.5 \mathrm{~cm}$. The highest value of number of spikelets /spike was 26 obtained at both $0.02 \%$ SA and $0.03 \% \mathrm{HZ}$ for mutated plants $\mathrm{S}_{1} 29$ and $S_{1} 75$ plants as compared to untreated plants (control) with 21.6 spikelet. The results (Table 3) showed that means of both number of grains /spikelet and 100grain weight were lower in $\mathrm{M}_{2}$ than $\mathrm{M}_{1}$ generation. The best reduced values in $\mathrm{M}_{2}$ generation were 4.9 and 5.55 obtained with $0.02 \%$ SA for mutant plant $\mathrm{S}_{1} 29$ as compared to 6.0 and $5.0 \mathrm{gm}$. in $\mathrm{M}_{1}$ generation for number of grains/spikelet and 100-grain weight, respectively. Finally, the data in Table (3) showed that significant differences among the different concentrations of two chemical mutagens (SA and HZ) in Sids 1 genotype in both $\mathrm{M}_{1}$ and $\mathrm{M}_{2}$ generations for all studied traits. These results agree with those reported by Saad et al. (2010), Beche et al. (2013) and Haridy and Abd El-Zaher (2015). They found that the average of 100 grain weight of treated plants increased significantly. Khursheed et al. (2015) found that mean values of 100 grain weight recorded higher in $\mathrm{M}_{2}$ generations than $M_{1}$ generation. and the average number of spikes per plant increased from 2.66 to 4.33 as a result to treat grains with $0.02 \% \mathrm{HZ}$. 
Table (3): Mean performance of Sids 1 genotype and the mutated selected plants at $\mathrm{M}_{1}$ and $\mathbf{M}_{2}$ generations for all studied traits in $2018 / 19$ and 2019/20 seasons.

\begin{tabular}{|c|c|c|c|c|c|c|c|c|}
\hline Genotypes & \multicolumn{2}{|c|}{ Treatments } & Plant height & $\begin{array}{l}\text { Number of } \\
\text { spikes/plant }\end{array}$ & Spike length & $\begin{array}{l}\text { Number of } \\
\text { spikelet/spike }\end{array}$ & $\begin{array}{l}\text { Number of } \\
\text { grains/spikelet }\end{array}$ & $\begin{array}{l}100 \text { - grain } \\
\text { weight }\end{array}$ \\
\hline \multirow{2}{*}{ Sids $_{1}$} & \multirow{2}{*}{ Control } & $\mathrm{M}_{1}$ & 103.0 & 13.0 & 14.0 & 22.0 & 3.0 & 5.3 \\
\hline & & $\mathrm{M}_{2}$ & $104.6 \pm 10.11 \mathrm{c}$ & $12.9 \pm 1.6 \mathrm{c}$ & $13.5 \pm 1.40 \mathrm{c}$ & $21.6 \pm 1.26 \mathrm{c}$ & $3.9 \pm 0.74 \mathrm{~b}$ & $5.0 \pm 0.13 \mathrm{c}$ \\
\hline \multirow{2}{*}{$S_{1}(29)$} & \multirow{2}{*}{$0.02 \mathrm{SA}$} & $\mathrm{M}_{1}$ & 105.0 & 59.0 & 18.0 & 24.0 & 6.0 & 6.0 \\
\hline & & $\mathrm{M}_{2}$ & $113.85 \pm 6.81 \mathrm{~b}$ & $58.7 \pm 17.30 \mathrm{a}$ & $19.1 \pm 1.39 \mathrm{a}$ & $26.0 \pm 1.33 \mathrm{a}$ & $4.9 \pm 0.99 \mathrm{a}$ & $5.55 \pm 0.15 \mathrm{a}$ \\
\hline \multirow{2}{*}{$S_{1}(42)$} & \multirow{2}{*}{$0.03 \mathrm{SA}$} & $\mathrm{M}_{1}$ & 105.0 & 103.0 & 17.0 & 26.0 & 5.0 & 6.2 \\
\hline & & $\mathrm{M}_{2}$ & $113.3 \pm 6.14 \mathrm{~b}$ & $38.2 \pm 16.61 \mathrm{~b}$ & $16.7 \pm 1.06 \mathrm{~b}$ & $24.4 \pm 1.26 \mathrm{~b}$ & $4.7 \pm 0.48 \mathrm{a}$ & $5.26 \pm 0.14 \mathrm{~b}$ \\
\hline \multirow{2}{*}{$S_{1}(75)$} & \multirow{2}{*}{$0.03 \mathrm{HZ}$} & $\mathrm{M}_{1}$ & 91.0 & 38.0 & 14.0 & 24.0 & 6.0 & 6.1 \\
\hline & & $\mathrm{M}_{2}$ & $121.6 \pm 4.55 \mathrm{a}$ & $44.7 \pm 11.29 \mathrm{~b}$ & $17.85 \pm 1.73 \mathrm{ab}$ & $26.0 \pm 1.89 \mathrm{a}$ & $4.7 \pm 0.82 \mathrm{a}$ & $5.46 \pm 0.13 \mathrm{a}$ \\
\hline \multicolumn{3}{|l|}{ Significant } & $*$ & $*$ & $*$ & $*$ & $*$ & $*$ \\
\hline \multicolumn{3}{|l|}{ LSD 0.05} & 6.52 & 12.04 & 1.28 & 1.32 & 0.71 & 0.13 \\
\hline
\end{tabular}

$\mathrm{M}_{1}=$ first mutagenicity value of one mutant plant, $\mathrm{M}_{2}=$ second mutagenicity mean value of ten mutant plants generations, * means significant at 0.05 levels of probability.

\subsubsection{Sids $_{12}$}

The data in Table (4) showed that the means of all studied traits in $\mathrm{M}_{1}$ and $\mathrm{M}_{2}$ generations of Sids 12 genotype and its mutant selected plants. Uniformly results showed that some mutations in $\operatorname{Sids}_{12}$ genotype increased in $\mathrm{M}_{2}$ than $\mathrm{M}_{1}$ generations. The highest value in plant height was $107.1 \mathrm{~cm}$ which obtained with $0.03 \% \mathrm{HZ}$ for mutated plant $S_{12} 168$ as compared to untreated plants (control) with $102.0 \mathrm{~cm}$. While the highest value in number of spikes /plant was 27.6 obtained with $0.02 \% \mathrm{HZ}$ for mutated plant $S_{12} 161$ as compared to original plants (control) with 8.4 spike. The highest value of spike length was $19.8 \mathrm{~cm}$ obtained at $0.03 \% \mathrm{HZ}$ for mutated plant $S_{12} 177$ compared to untreated plants (control) with $13.4 \mathrm{~cm}$. The highest value of number of spikelets /spike was 26 obtained at both $0.03 \% \mathrm{HZ}$ for mutated plants $S_{12} 177$ as compared to control with 20.4 spikelet. The highest value of number of grains /spikelets was 6.9 obtained at both $0.03 \%$ SA for mutated plants $S_{12} 116$ as compared to untreated plants (control) with 3.4 grain. The highest value of 100 -grain weight was $6.31 \mathrm{~g}$ obtained at both $0.02 \% \mathrm{HZ}$ for mutated plants $S_{12} 161$ as compared to untreated plants (control) with $4.18 \mathrm{gm}$. These results showed that means of $\mathrm{M}_{2}$ generation of $\mathrm{Sids}_{12}$ genotype in the four mutant selected plants were higher than those obtained from $\mathrm{M}_{1}$ generation for most studied traits. Also, data in Table (4) showed that significant differences among the different concentrations of two chemical mutagens (SA and HZ) in Sids 12 genotype in both $M_{1}$ and $M_{2}$ generations for all studied traits. Mensah and Obadoni (2007) reported that increasing shoots number per plant in $M_{2}$ than $M_{1}$ generation. Khursheed et al. (2015) and Khah and Verma (2015) reported that mutagen treatment increased spike length positively. Mensah and Obadoni (2007), Khah and Verma (2015), and Khursheed et al. (2015) recorded positive shifts in mean values of plant height because of the mutagen treatment. 
Table (4): Mean performance of $\operatorname{Sids}_{12}$ genotype and the mutated selected plants at $\mathrm{M}_{1}$ and $\mathbf{M}_{2}$ generations for all studied traits in 2018/19 and 2019/20 seasons.

\begin{tabular}{|c|c|c|c|c|c|c|c|c|}
\hline Genotypes & \multicolumn{2}{|c|}{ Treatments } & Plant height & $\begin{array}{l}\text { Number of } \\
\text { spikes/plant }\end{array}$ & Spike length & $\begin{array}{l}\text { Number of } \\
\text { spikelet/spike }\end{array}$ & $\begin{array}{l}\text { Number of } \\
\text { grains/spikelet }\end{array}$ & $\begin{array}{l}100 \text { - grain } \\
\text { weight }\end{array}$ \\
\hline \multirow{2}{*}{ Sids $_{12}$} & \multirow{2}{*}{ Control } & $\mathrm{M}_{1}$ & 98.0 & 9.0 & 12.0 & 22.0 & 4.0 & 5.2 \\
\hline & & $\mathrm{M}_{2}$ & $102.0 \pm 2.66 \mathrm{bc}$ & $8.4 \pm 2.07 \mathrm{~d}$ & $13.4 \pm 0.39 \mathrm{~b}$ & $20.4 \pm 1.58 \mathrm{~b}$ & $3.4 \pm 0.52 \mathrm{c}$ & $4.18 \pm 0.18 \mathrm{c}$ \\
\hline \multirow{2}{*}{$S_{12}(116)$} & \multirow{2}{*}{$0.02 \mathrm{SA}$} & $\mathrm{M}_{1}$ & 98.0 & 18.0 & 19.0 & 30.0 & 7.0 & 5.9 \\
\hline & & $\mathrm{M}_{2}$ & $100.4 \pm 5.27 \mathrm{c}$ & $14.3 \pm 5.89 \mathrm{c}$ & $19.25 \pm 2.28 \mathrm{a}$ & $25.6 \pm 2.27 \mathrm{a}$ & $6.9 \pm 1.97 \mathrm{a}$ & $5.95 \pm 0.43 \mathrm{~b}$ \\
\hline \multirow{2}{*}{$S_{12}(161)$} & \multirow{2}{*}{$0.03 \mathrm{SA}$} & $\mathrm{M}_{1}$ & 103.0 & 14.0 & 15.5 & 24.0 & 7.0 & 6.1 \\
\hline & & $\mathrm{M}_{2}$ & $102.9 \pm 3.03 \mathrm{bc}$ & $27.6 \pm 6.04 \mathrm{a}$ & $19.0 \pm 0.82 \mathrm{a}$ & $25.2 \pm 2.86 \mathrm{a}$ & $5.3 \pm 1.06 \mathrm{~b}$ & $6.31 \pm 0.29 \mathrm{a}$ \\
\hline \multirow{2}{*}{$S_{12}(168)$} & \multirow{2}{*}{$0.03 \mathrm{HZ}$} & $\mathrm{M}_{1}$ & 81.0 & 17.0 & 18.0 & 24.0 & 10.0 & 5.8 \\
\hline & & $\mathrm{M}_{2}$ & $107.1 \pm 1.91 \mathrm{a}$ & $24.4 \pm 3.21 \mathrm{ab}$ & $19.75 \pm 1.21 \mathrm{a}$ & $22.0 \pm 1.63 \mathrm{~b}$ & $4.8 \pm 0.82 \mathrm{~b}$ & $6.01 \pm 0.32 \mathrm{~b}$ \\
\hline \multicolumn{3}{|l|}{ Significant } & $*$ & $*$ & $*$ & $*$ & $*$ & $*$ \\
\hline \multicolumn{3}{|l|}{ LSD 0.05} & 2.99 & 4.47 & 1.15 & 1.77 & 0.82 & 4.17 \\
\hline
\end{tabular}

$\mathrm{M}_{1}=$ first mutagenicity value of one mutant plant, $\mathrm{M}_{2}=$ second mutagenicity mean value of ten mutant plants generations, * means significant at 0.05 levels of probability.

\subsubsection{Giza 168}

The results in Table (5) showed that means of the studied traits in $\mathrm{M}_{1}$ and $\mathrm{M}_{2}$ generations of Giza $_{168}$ genotype and one mutant selected plant Giza 168 202. Means of most studied traits increased in $\mathrm{M}_{2}$ than $\mathrm{M}_{1}$ generation in mutant selected plant Giza $_{168} 202$, which obtained with $0.02 \%$ $\mathrm{SA}$. The increased values were $106 \mathrm{~cm}$ for plant height, 25.1 for number of spikes /plant, 19.9 for spike length, $27 \mathrm{~cm}$ for number of spikelet /spike, 5.77 for 100grain weight as compared to untreated plants (control) with 94.1, 12.1, 13.35, 21.6, 4.0 and 4.09, respectively. However, number of grains /spikelet reduced from 7 in $\mathrm{M}_{1}$ to 5.7 in $\mathrm{M}_{2}$ generation. The data in Table (5) showed that significant differences between treated with $0.02 \%$
SA and untreated plants (control) in Giza 168 genotype in both $\mathrm{M}_{1}$ and $\mathrm{M}_{2}$ generations for all studied traits. These results were agreement with those obtained by Fikre et al. (2015) showed significant variation for all the traits studied i.e., number of spikelet /spike, spike length and plant height after mutagen treatment. Ahmed et al. (2016) reported increasing of spike length and hundred-grain weight after mutagen treatment. Al-Nuaimi and Al-Shamma (2015) reported that all mutations showed significant increase in plant height and number of tillers per plant compared with control plants. However, the results of present study disagree with those obtained by Khah and Verma (2015) which found decrease in number of spikelets /spike after mutagen treatment.

Table (4): Mean performance of Giza 168 genotype and one mutated selected plant at $\mathrm{M}_{1}$ and $\mathrm{M}_{2}$ generations for all studied traits in 2018/19 and 2019/20 seasons.

\begin{tabular}{|l|l|l|l|l|l|l|l|l|}
\hline Genotypes & \multirow{2}{*}{ Treatments } & Plant height & $\begin{array}{l}\text { Number of } \\
\text { spikes/plant }\end{array}$ & Spike length & $\begin{array}{l}\text { Number of } \\
\text { spikelet/spike }\end{array}$ & $\begin{array}{l}\text { Number of } \\
\text { grains/spikelet }\end{array}$ & $\begin{array}{l}100 \text { - grain } \\
\text { weight }\end{array}$ \\
\hline \multirow{2}{*}{ Giza 168} & \multirow{2}{*}{ Control } & $\mathrm{M}_{1}$ & 95.0 & 10.0 & 13.0 & 24.0 & 4.0 & 4.2 \\
\cline { 3 - 10 } & $\mathrm{M}_{2}$ & $94.1 \pm 3.25 \mathrm{~b}$ & $12.0 \pm 4.80 \mathrm{~b}$ & $13.35 \pm 0.85 \mathrm{~b}$ & $21.6 \pm 1.58 \mathrm{~b}$ & $4.0 \pm 0.67 \mathrm{~b}$ & $4.09 \pm 0.13 \mathrm{~b}$ \\
\hline \multirow{2}{*}{$\mathrm{G}_{168}(202)$} & \multirow{2}{*}{$0.02 \mathrm{SA}$} & $\mathrm{M}_{1}$ & 105.0 & 21.0 & 18.0 & 26.0 & 7.0 & 5.3 \\
\cline { 3 - 10 } & $\mathrm{M}_{2}$ & $106.0 \pm 5.31 \mathrm{a}$ & $25.1 \pm 4.04 \mathrm{a}$ & $19.9 \pm 0.84 \mathrm{a}$ & $27.0 \pm 1.70 \mathrm{a}$ & $5.7 \pm 1.06 \mathrm{a}$ & $5.79 \pm 0.39 \mathrm{a}$ \\
\hline Significant & & $*$ & $*$ & $*$ & $*$ & $*$ & \\
\hline \multicolumn{2}{l}{ LSD 0.05 } & 4.14 & 4.17 & 0.80 & 1.54 & 0.83 & 0.27 \\
\hline
\end{tabular}

$\mathrm{M}_{1}=$ first mutagenicity value of one mutant plant, $\mathrm{M}_{2}=$ second mutagenicity mean value of ten mutant plants generations, * means significant at 0.05 levels of probability. 


\subsection{SSR molecular marker}

Seven SSR primers were used to amplify fragments in all selected $\mathrm{M}_{2}$ generation for the three varieties and its original varieties (control). Primer xgwm99 (Figure 1 A) generated five bands in Sids1 and their three selected mutant plants with DNA size ranged from $110 \mathrm{bp}$ to $720 \mathrm{bp}$, lane 1 to 4 respectively. Three bands out of them were monomorphic and two bands were polymorphic and showed $40 \%$ polymorphism. In the same figure lane 5 to 9 presented molecular fragments amplified by Sids 12 variety and their four selected mutant plants respectively with DNA size ranged from $110 \mathrm{bp}$ to $720 \mathrm{bp}$. Three bands were produced, two bands were monomorphic, and one band was polymorphic and showed $33.3 \%$ polymorphism. In the same figure lane 10 to 11 presented molecular fragments amplified by Giza 168 variety and its selected mutant plants respectively with DNA size ranged from $110 \mathrm{bp}$ to $720 \mathrm{bp}$. four bands were produced; two bands were monomorphic, and two bands were polymorphic showed $50 \%$ polymorphism.
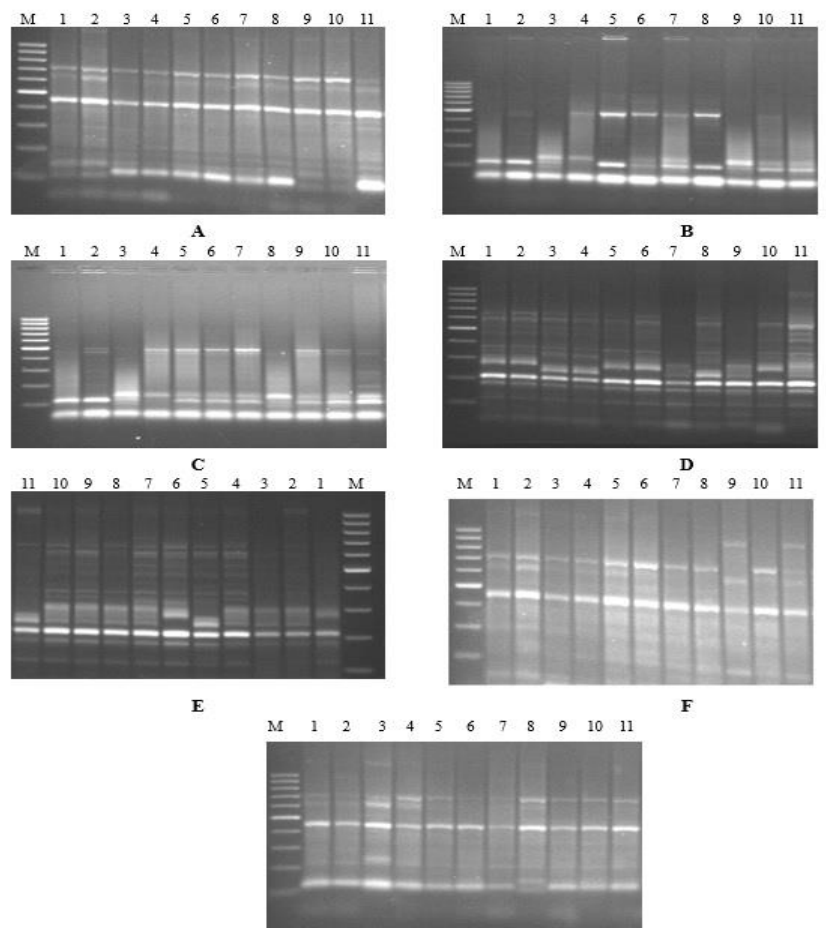

Figure (1): SSR banding patterns among 11 genotypes, (1) $\operatorname{Sids}_{1}$, (2) $\mathrm{S}_{1} 29$, (3) $S_{1} 42$, (4) $S_{1} 75$, (5) $\operatorname{Sids}_{12}$, (6) $S_{12} 116$, (7) $S_{12} 161$, (8) $S_{12} 168$, (9) $S_{12}$ 177, (10) Giza 168 , (11) Giza 168202 for xgwm99 primer (A), xgwm186 primer (B), Xgwm337 primer (C), Xgwm357 primer (D), xgwm484 primer (E), xgwm626 primer $(F), x p s p 3200$ primer $(G)$, and marker is $1000 \mathrm{bp}$. 
Primer xgwm186 (Figure 1B) generated four bands in Sids1 and their three selected mutant plants, lane 1 to 4 respectively with DNA size ranged from 75 bp to 490 bp. One band was monomorphic, and three bands were polymorphic and showed $75 \%$ polymorphism. In the same figure lane 5 to 9 presented molecular fragments amplified by using $\operatorname{Sids}_{12}$ and their four selected mutant plants respectively with DNA size ranged from $75 \mathrm{bp}$ to $490 \mathrm{bp}$. Four bands were produced, one band was monomorphic, and three bands were polymorphic and showed $75 \%$ polymorphism. In the same figure lane 10 to 11 presented molecular fragments amplified by Giza168 and its selected mutant plants respectively with DNA size ranged from $75 \mathrm{bp}$ to $120 \mathrm{bp}$. three bands were produced, two bands were monomorphic, and one band was polymorphic and showed 33.3\% polymorphism. Primer xgwm337 (Figure 1C) generated four bands in Sids 1 and their three selected mutant plants, lane 1 to 4 respectively with DNA size ranged from $75 \mathrm{bp}$ to $500 \mathrm{bp}$. one band was monomorphic, and three bands were polymorphic and showed $75 \%$ polymorphism. In the same figure lane 5 to 9 presented molecular fragments amplified by using $\operatorname{Sids}_{12}$ and their four selected mutant plants with DNA size ranged from $75 \mathrm{bp}$ to $500 \mathrm{bp}$. four bands were produced; two bands were monomorphic, and two bands were polymorphic and showed 50\% polymorphism. In the same figure, lane 10 to 11 presented molecular fragments amplified by using Giza 168 and its selected mutant plant with DNA size ranged from $75 \mathrm{bp}$ to $500 \mathrm{bp}$. five bands were produced, four bands were monomorphic, and one band was polymorphic and showed $20 \%$ polymorphism. Primer xgwm357 (Figure 1D) generated four bands in Sids 1 and their three selected mutant plants, lane 1 to 4 respectively with DNA size ranged from $210 \mathrm{bp}$ to 600 bp. two bands were monomorphic, and two bands were polymorphic and showed $50 \%$ polymorphism. In the same figure lane 5 to 9 presented molecular fragments amplified by using Sids 12 and their four selected mutant plants respectively with DNA size ranged from $210 \mathrm{bp}$ to $600 \mathrm{bp}$. Four bands were produced, one band was monomorphic, and three bands were polymorphic and showed $75 \%$ polymorphism. In the same figure lane 10 to 11 presented molecular fragments amplified by using Giza 168 and its selected mutant plant respectively with DNA size ranged from $210 \mathrm{bp}$ to $600 \mathrm{bp}$. Three bands were produced, three bands were monomorphic and no polymorphic bands and showed 0\% polymorphism. Primer xgwm484 (Figure 1E) generated three bands in Sids 1 and their three selected mutant plants, lane1 to 4 respectively with DNA size ranged from $210 \mathrm{bp}$ to $600 \mathrm{bp}$. Two bands were monomorphic, and one band was polymorphic and showed 33.3\% polymorphism. In the same figure lane 5 to 9 presented molecular fragments amplified by using $\operatorname{Sids}_{12}$ and their four selected mutant plants respectively with 
DNA size ranged from $210 \mathrm{bp}$ to $600 \mathrm{bp}$. five bands were produced; one band was monomorphic, and four bands were polymorphic and showed $80 \%$ polymorphism. In the same figure lane 10 to 11 presented molecular fragments amplified by Giza 168 variety and its selected mutant plant respectively with DNA size ranged from $210 \mathrm{bp}$ to $600 \mathrm{bp}$. four bands were produced; two bands were monomorphic, and two bands were polymorphic and showed 50\% polymorphism. Primer xgwm626 (Figure 1F) generated three bands in Sids 1 and their three selected mutant plants, lane 1 to 4 respectively with DNA size ranged from $450 \mathrm{bp}$ to $720 \mathrm{bp}$. Two bands were monomorphic, and one band was polymorphic and showed $33.3 \%$ polymorphism. In the same figure lane 5 to 9 presented molecular fragments amplified by Sids 12 variety and their four selected mutant plants respectively with DNA size ranged from $450 \mathrm{bp}$ to $900 \mathrm{bp}$. Four bands were produced, one band was monomorphic, and three bands were polymorphic and showed $75 \%$ polymorphism. In the same figure lane 10 to 11 presented molecular fragments amplified by Giza 168 and its selected mutant plant with DNA size ranged from $450 \mathrm{bp}$ to $900 \mathrm{bp}$. Four bands were produced, two bands were monomorphic, and two bands were polymorphic and showed 50\% polymorphism. Primer xpsp3200 (Figure 1G) generated five bands in Sids 1 and their three selected mutant plants, lane 1 to 4 respectively with DNA size ranged from $110 \mathrm{bp}$ to 700 bp. Three bands were monomorphic, and two bands were polymorphic and showed $40 \%$ polymorphism. In the same figure lane 5 to 9 presented molecular fragments amplified by Sids $_{12}$ and their four selected mutant plants respectively with DNA size ranged from $110 \mathrm{bp}$ to $700 \mathrm{bp}$. three bands were produced; two bands were monomorphic, and one band was polymorphic and showed 33.3\% polymorphism. In the same figure lane 10 to 11 presented molecular fragments amplified by Giza 168 and its selected mutant plant respectively with DNA size ranged from $110 \mathrm{bp}$ to $700 \mathrm{bp}$. three bands were produced; three bands were monomorphic and no polymorphic band and showed $0 \%$ polymorphism. The highest levels of polymorphism for SSRs system compared to other systems also reported in previous studies by Brbaklic et al. (2015), Faheem et al. (2015), Hao et al. (2011), Nagy et al. (2012), Ramadugu et al. (2015), Ramya et al. (2015), Ateş Sönmezoğlu and Terzi (2018), and Tomar et al. (2016). This high level of polymorphism, associated with SSR markers, is to be expected because of the unique mechanism responsible for generating SSR allelic diversity (Abbasov et al., 2019). The codominant nature of SSR markers also permits the detection of a high number of alleles per locus and contributes to higher levels of expected heterozygosity being reached than would be possible with RAPD markers (Hao et al., 2006). 


\section{Conclusion}

In conclusion, the results of this study provided most morphological and agronomical traits increased in the selected mutant plants as a result of mutagen treatment as compared to untreated plants (control) . Also, most morphological and agronomical traits showed more increase in $\mathrm{M}_{2}$ generation than $\mathrm{M}_{1}$ generation for most studied traits. Moreover, results showed that significant differences among the different concentrations of two chemical mutagens (SA and HZ) in the treated and untreated of the three varieties of bread wheat i.e., Sids $_{1}$, Sids $_{12}$ and Giza 168 for both $\mathrm{M}_{1}$ and $\mathrm{M}_{2}$ generations for most studied traits. And in molecular studied were showed represpectable the variation between treated genotyes and untreated (control) for all studied traits. in all selected $\mathrm{M}_{2}$ plants were used to evaluate variation by SSR molecular markers. Finaly, the SSR marker identify developed from this study can be used to identify mutation genotypes in wheat with chemical mutagen.

\section{References}

Abbasov, M., Brueggeman, R., Raupp, J., Akparov, Z., Aminov, N., Bedoshvili, D., Gross, T., Gross, P., Babayeva, S., Izzatullayeva, V., Mammadova, A., Hajiyev, E., Rustamov, K. and Gill, B. S. (2019), "Genetic diversity of Aegilops L. species from Azerbaijan and Georgia using SSR markers", Genetic
Resources and Crop Evolution, Vol. 66, pp. 453-463.

Ahmed, M., Qadeer, U., Ahmed, Z. I. and Hassan, F. (2016), "Improvement of wheat (Triticum aestivum L.) drought tolerance by seed priming with silicon", Archives of Agronomy and Soil Science, Vol. 3, pp. 299-315.

Al-Naggar, A. M. M., Sabry, S. R. S., Atta, M. M. M. and Abd El-Aleem, O. M. (2015), "Effects of salinity on performance, heritability, selection gain and correlations in wheat (Triticum aestivum L.) doubled haploids", Scientia Agriculturae, Vol. 10, pp. 70-83.

Al-Nuaimi, F. K. G. and Al-Shamma, L. M. J. (2015), "Effect of chemical mutagens on some morphological traits of Vicia faba L. cv. Aqadulce", Iraqi Journal of Science, Vol. 56, pp. 2506-2512.

Altintas, S., Toklu, F., Kafkas, S., Kilian, B., Brandolini, A. and Ozkan, H. (2008), "Estimating genetic diversity in durum and bread wheat cultivars from Turkey using AFLP and SAMPL markers", Plant Breed, Vol. 127, pp. 9-14.

Ateş Sönmezoğlu, Ö. and Terzi, B. (2018), "Characterization of some bread wheat genotypes using molecular markers for drought tolerance", Physiology and Molecular Biology of Plants, Vol. 24, pp. 159-166.

Babben, S., Schliephake, E., Janitza, P., 
Berner, T., Keilwagen, J., Koch, M., Arana Ceballos, F. A., Templer, S. E., Chesnokov, Y., Pshenichnikova, T., Schondelmaier, J., Borner, A., pillen, K., Ordon, F. and Perovic, D. (2018), "Association genetics studies on frost tolerance in wheat (Triticum aestivume L.) reveal new highly conserved amino acid substitutions in CBF-A3,CBF-A15,VRN3 and PPD1 genes", BMC Genomics, Vol. 19, pp. $1-24$.

Beche, E., Silva, C. L., Pagliosa, E. S., Capelin, M. A., Franke, J., Matei, G. and Benin, G. (2013), "Hybrid performance and heterosis in early segregate population of brazilian spring wheat", Australian Journal of Crop Science, Vol. 1, pp. 51-57.

Brbaklic, L., Trkulja, D., Kondic-Spika, A., Mikih, S., Tomičić, M. and Kobiljski, B. (2015), "Determination of population structure of wheat core collection for association mapping", Cereal Research Communications, Vol. 1, pp. 22-28.

Doyle, J. J. and Doyle, J. L. (1987), "A rapid DNA isolation procedure for small quantities of fresh leaf tissue", Photochemistry Bulletin, Vol. 19, pp. 11-15.

El-Sherbeny, G. A. R., Omara, M. K., Ashraf, A., Farrage, A. A. and Khaled, A. G. A. (2020), "Associations between ISSR markers and quantitative traits in bread wheat genotypes", Asian Journal of Research in Biosciences, Vol .1, pp. 1-8.
Ercan, S., Ertugrul, F., Aydin, Y. and Akfirat-Senturk, F. (2010), "An ESTSSR marker linked with yellow rust resistance in wheat", Biologia Plantarum, Vol. 54, pp. 691-696.

Faheem, M., Mahmood, T., Shabbir, G., Akhtar, N., UL Kazi, A. G. and Kazi, A. M. (2015), "Assessment of Dgenome based genetic diversity in drought tolerant wheat germplasm", International Journal of Agriculture and Biology, Vol. 17, pp. 791-796.

Farhan, M. B., Abdulhamed, Z. A., Noaman, A. H., Nihad, M. and Abod, N. M. (2019), "Determination of genetic distance among genotypes of bread wheat Triticum aestivum L., using ISSR markers", Plant Archives, Vol. 19, pp. 455-459.

Fikre, G., Alamerew, S. and Tadesse, Z. (2015), "Genetic variability studies in bread wheat (Triticum aestivum L.) genotypes at Kulumsa Agricultural Research Center, South East Ethiopia", Journal of Biology, Agriculture and Healthcare, Vol. 5, pp. 89-98.

Gel Analyzer (2007), Gel Analyzer, Version 3, program software for windows, available at www.geocities.com/egygene.

Hao, C. Y., Zhang, X. Y., Wang, L. F., Dong, Y. S., Shang, X. W. and Jia, J. Z. (2006), "Genetic diversity and core collection evaluations in common wheat germplasm from the northwestern spring wheat region in China", Molecular Breeding, Vol. 
17, pp. 69-77.

Hao, C., Wang, L., Ge, H., Dong, Y. and Zhang, X. (2011), "Genetic diversity and linkage disequilibrium in Chinese bread wheat (Triticum aestivum L.) revealed by SSR markers", PLOS ONE, Vol. 6, pp. 113.

Haridy, M. H. and Abd El-Zaher, I. N. (2015), "Heterosis and combining ability in bread wheat (Triticum aestivum, L.)", Minia Journal of Agricultural Research and Development, Vol. 35, pp. 59-67.

Hussain, M., Iqbal, M. A., Till, B. J. and Ur-Rahman, M. (2018), "Identification of induced mutations in hexaploid wheat genome using exome capture assay", PLOS ONE, Vol. 13, pp. 1-22.

Khah, M. A. and Verma, R. C. (2015), "Assessment of the effects of gamma radiations on various morphological and agronomic traits of common wheat (Triticum aestivum L.) var. WH-147", European Journal of Experimental Biology, Vol. 7, pp. 611.

Khursheed, S., Fatima, S. and Khan, S. (2015), "Differential genotypic response of two varieties of (Hordeum vulgare L.) in response to hydrazine hydrate alone and in combination with dimethyl sulfoxide", Journal of Phytology, Vol. 7, pp. 19-25.

Laskar, R. A. and Khan, S. (2017),
"Mutagenic effectiveness and efficiency of gamma rays and $\mathrm{HZ}$ with phenol typing of induced mutations in lentil cultivars", International Letters of Natural Sciences, Vol. 64, pp. 17-31.

Mensah, J. K. and Obadoni, B. (2007), "Effects of sodium azide on yield parameters of groundnut (Arachis hypogaea L.)", African Journal of Biotechnology, Vol. 6, pp. 668-671.

Mohamed, R., Kabir, M. R., Hoque, M. E. and Akhond, M. A. Y. (2018), "Assessment of some genetic attributes in wheat (Triticum aestivum L.) using gene-specific molecular markers", Agriculture and Natural Resources, Vol. 52, pp. 3944.

Nagy, S., Poczai, P., Cerna, k. I., Gorji, A. M., Hegedüs, G. and Taller, J. (2012), "PICcalc: an online program to calculate polymorphic information content for molecular genetic studies", Biochemical Genetics, Vol. 50, pp. 670-672.

Nazarenko, M. (2016), "Parameters of winter wheat growing and development after mutagen action", Agricultural Food Engineering, Vol. 58, pp. 109-116.

Nielsen, N. H., Backes, G., Stougaard, J., Andersen, S. U. and Jahoor, A. (2014), "Genetic diversity and population structure analysis of European hexaploid bread wheat (Triticum aestivum L) varieties", PLOS ONE, Vol. 9, pp. 1-13. 
Pande, S. and Khetmalas, M. (2012), Biological effect of sodium azide and colchicine on seed germination and callus induction in Stevia Rebaudiana", Asian Journal of experimental Biological sciences, Vol. 1, pp. 93-98.

Ramadugu, C., Keremane, M. L., Hu, X., Karp, D., Federici, C. T., Kahn, T. and Lee, R. F. (2015), "Genetic analysis of citron (Citrus medica L.) using simple sequence repeats and single nucleotide polymorphisms", Scientia Horticulturae, Vol. 195, pp. 124-137.

Ramya, P., Jain, N., Singh, P. K., Singh, G. P. and Prabhu, K. V. (2015), "Population structure, molecular and physiological characterisation of elite wheat varieties used as parents in drought and heat stress breeding in India",

Indian Journal of Genetics and Plan t Breeding, Vol. 75, pp. 250-252.

Saad, F. F., Abo-Hegazy, S. R. E., ElSayed, E. A. M. and Suleiman, H. S. (2010), "Heterosis and combining ability for yield and components in diallel crosses among seven bread wheat genotypes", Egyptian Journal of Plant Breeding, Vol. 14, pp. 7-22.

Sadigova, S., Sadigov, H., Eshghi, R., Salayeva, S. and Ojagh, J. (2014), "Application of RAPD and ISSR markers to analyses molecular relationships in Azerbaijan wheat accessions (Triticum aestivum L.)", Bulgarian Journal of Agricultural Science, Vol. 20, pp. 87-95.
Singh, N. K. and Balyan, H. S. (2009), "Induced mutation in bread wheat (Triticum aestivum L.) cv. Kharchia 65 for reduced plant height and improve grain quality traits", Advances in Biological Research, Vol. 3, pp. 215-221.

Singh, P. and Singh, N. K. (2018), "SSR molecular marker are efficient tools for finding genetic diversity in bread wheat", International Journal of Current Microbiology and Applied Sciences, Vol. 7, pp. 1098-1105.

Steel, R. G. D. and Torrie, J. H. (1986), Principle and Procedure of statistics: A Biometrical Approach, $2^{\text {ed }}$ ed., McGraw-Hill Book Co., New York, USA.

Tomar, R. S. S., Tiwari, S., Naik, B. K., Chand, S., Deshmukh, R., Mallick, N. and Tomar, S. M. S. (2016), "Molecular and morpho-agronomical characterization of root architecture at seedling and reproductive stages for drought tolerance in wheat", PLOS ONE, Vol. 11, pp. 156-528.

Wani, M. R. (2017), "Induced chlorophyll mutations, comparative mutagenic effectiveness and efficiency of chemical mutagenes in lentils (Lens culinaris Medik)", Asian Journal of Plant Sciences, Vol. 16, pp. 221226. 